\title{
Evolutionary Economics and the Markets-as-Networks Approach
}

\author{
Ross Brennan \\ Middlesex University Business School \\ The Burroughs \\ Hendon NW4 4BT \\ United Kingdom \\ Tel. +44 (0)20 84115861 \\ Email r.brennan@mdx.ac.uk
}

\begin{abstract}
The premise of this paper is that the systematic comparison of the markets-as-networks research tradition with cognate research traditions in the social and management sciences will bring about a fruitful cross-fertilisation of ideas, potentially resulting in the creation of an enriched research agenda. Specifically, the paper analyses the similarities and differences between the markets-as-networks (or IMP) tradition and evolutionary economics. Five analytical dimensions are used: unit of analysis, methodological practice, core frameworks \& models, key assumptions, and theoretical antecedents \& origins. Evolutionary ideas have long been incorporated into economic theorising. This paper concentrates on evolutionary economics arising out of the old institutional economics of Veblen (1899), which has been substantially inspired by Schumpeter (Fagerberg, 2003) - and is often referred to as neoSchumpeterian - and which has culminated in a research tradition centred on the work of Nelson and Winter (1982). There are several important parallels between this research tradition and the IMP or markets-as-networks tradition, notably the shared rejection of neoclassical economic assumptions (rational economic man, economic optimization) and the adoption of behaviourist theories such as satisficing and bounded rationality. However, there are differences in terms of the unit of analysis and the fundamental aims of these two research traditions. Evolutionary economics retains the traditional assumption of the firm and the market as the fundamental units of analysis within an economic system, and seeks to elucidate broad economic policy themes. Markets-as-networks, as conceived by prominent researchers Ford and Håkansson (2005), queries the independent decision-making capabilities of individual firms and makes the interaction and the network the units of analysis; the overall aims of this tradition are less heroic than those of evolutionary economics. It is proposed that the markets-as-networks tradition could be enriched by seeking explicitly to incorporate elements of an evolutionary process into the dynamics of change within inter-firm relationships and networks. Evolutionary economics, it is suggested, would benefit from explicit consideration of the likelihood that inter-organizational routines, rather than individual firm-based routines, play an important part in the evolutionary process.
\end{abstract}

Keywords: Markets-as-networks; evolutionary economics; old institutional economics; routines 


\section{Introduction}

"We must act in the space between optimality and randomness." (Loasby, 2001)

Brian Loasby expresses with great economy an idea that is important to theoreticians from both the evolutionary economics (EE) and markets-as-networks (NW) research traditions. He rejects fully rational, optimising economic behaviour on the grounds that this makes untenable assumptions about human knowledge. However, in rejecting optimality he does not advocate neo-Darwinian evolutionary models of economic behaviour, which exclude human purpose as a factor in economic change. Rather, economic action takes place somewhere between these two extremes. This economic "space between" has been investigated for several decades by researchers from both the new evolutionary economics school and from the IMP or marketsas-networks school. Yet these streams of research have run virtually on parallel courses, never crossing, and with little cross-referencing.

Mattsson (1997) and Araujo (2004), as prominent researchers in the NW school, have both found merit in investigating the potential for cross-fertilisation with other schools of thought in management studies and the social sciences. Mattsson compared the NW approach with relationship marketing, while Araujo investigated ideas in economic sociology associated with Callon (Callon, Méadel, \& Rabeharisoa, 2002; D. Miller, 2002). The fundamental contention of this paper is that further comparison between the NW literature and other research traditions in the social sciences that investigate the same or related phenomena is a fruitful endeavour. Specifically, in this paper the focus is upon the new evolutionary economics, particularly that branch associated with Nelson and Winter (1982).

It is not difficult to make a prima facie case for the legitimacy of a comparison of NW and EE. In a recent article in the Journal of Evolutionary Economics, Fagerberg (2003, p150), explained that:

"... evolutionary economics - and in particular the formal literature - looks at the social and economic consequences of interaction within populations of heterogeneous actors."

The fundamental purpose of the NW project is to understand interaction within networks of heterogeneous business organizations. As we will see, both schools of thought emerged from a sense of dissatisfaction with the orthodox theory of the latter half of the twentieth century. In the case of EE this was quite explicitly neoclassical economics, while for NW theory this was the marketing mix paradigm, which itself owes a large intellectual debt to neoclassical economics.

The argument proceeds as follows. The next section provides a historical background to the development of institutional and evolutionary economics, followed by a description of the approach adopted by Nelson and Winter, and concludes with some discussion of criticisms levelled at the evolutionary approach in economics. There is then a short description of the background and main features of the NW approach, which is kept brief because the intended audience for this paper is assumed to be familiar with this research tradition. This is followed by an analytical section in which the EE and the NW approaches are compared and contrasted in terms of their unit of analysis, methodological practice, core frameworks \& models, key assumptions, and theoretical antecedents \& origins. The paper then concludes with some final observations on the legitimacy and value of undertaking a comparative analysis of the two research traditions, and the possible research directions that emerge from this analysis. 


\section{Institutional and evolutionary economics}

\section{Neoclassical and institutional economics}

As Miller and Mair (1991) have argued, even among those trained in economics there is a tendency to equate the entire field with the currently dominant school of thought, namely the neoclassical-Keynesian synthesis. Those from outwith the field of economics can therefore be reasonably excused such confusion. Gee (1991, p71) explained that:

"There can be no doubt that the neoclassical school of economics is the dominant school of economics in the western world".

For this school of thought rational, maximising individuals exist within an atomistic society, in an economic system that tends towards equilibrium and can therefore be analysed fruitfully in terms of comparative statics. There is great emphasis on the use of formal, mathematical modelling, the roots of which can be traced to the mechanical analogies used by pioneers such as Jevons in the eighteenth century (Grattan-Guinness, 2002; Jevons, 1871/1970). The essential logic of this school of thought is not, generally, that their assumptions are a good description of how human beings actually behave. Rather, these are necessary simplifying assumptions if working models of the economic system are to be built. The pay-off for making unrealistic simplifying assumptions about individual economic agents is that one can develop models that illuminate system-wide effects. The modern critique of neoclassical economic models from within economics starts from the claim that they do not, in practice, explain or predict the working of market systems well, so that the justification for the simplifications about human behaviour that they make is unsustainable. Lawson (2003) developed this argument, while focusing his primary attack on the implicit ontological assumptions that are inherent in the mathematical modelling techniques of neoclassical economics. Several alternatives to neoclassical economics have emerged, categorised under the general heading of heterodox economics. Evolutionary economics is one of these alternatives, lying within the institutional economics school of thought.

Foster (1991) provided a historical account of the development of institutional economics and, within this field, of the particular emergence of Galbraith (1967), the "evolutionary dynamics" group (within which he locates Nelson and Winter), and of Williamson's new institutional economics (Williamson, 1975). He argued that institutionalism was the dominant school in the inter-war period, but was overtaken by the neoclassical school in the post-war period because of the presumed scientific superiority of mathematical methods in economics. The origins of institutionalism lie in Veblen's work (Veblen, 1898, 1899), and a critique of neoclassical economics because of its unrealistic assumptions about "rational economic man", static equilibrium analysis, and neglect of economic institutions. The central problem of institutional economics is taken to be the organization and control of the economic system, on the argument that power relations take precedence over the price mechanism as the force governing economic outcomes. The archetypal "auction" assumed in neoclassical economics is but one of many different types of institution. The links between economic institutions and other institutions (legal, political, and so on) is considered important. Both Foster (1991) and Hodgson (1993) argued that the ontological basis for the institutional school in economics was to be found in the pragmatism of American philosophers such as Peirce and Dewey.

Within the evolutionary dynamics of the institutionalist school, Foster discussed Boulding, Schumpeter, and then Nelson and Winter, whom he categorised as neo-Schumpeterian. Joseph Schumpeter is probably the most frequently cited intellectual progenitor of EE. Schumpeter himself often wrote about the relevance of evolutionary thinking in economics, for example:

"Social phenomena constitute a unique process in historic time, and incessant and irreversible change is their most obvious characteristic. If by evolutionism we mean not more than recognition of this fact, then all reasoning about social phenomena must be either 
evolutionary in itself or else bear upon evolution. Here, however, evolutionism is to mean more than this." (Schumpeter, 1954, p435).

\section{Schumpeter, Alchian and new evolutionary economics}

Schumpeter found much to admire in the neoclassical school of economics, in particular the mathematical precision of neoclassical models. However, he argued that firms compete mainly in terms of technological progress rather than on price, with technological progress broadly defined to include the exploitation of new markets and new methods of organizing. Consequently, Schumpeter emphasized the importance of innovation and of the entrepreneur. This led him to an evolutionary view of capitalist development, as firms compete with each other by introducing innovations which then spawn imitators and lead to economic development and progress. The problem for Schumpeter was that the mathematical techniques and computational power available in his day were insufficient to transform his conceptual models into formal, mathematical models. One strand of economic work inspired by Schumpeter concentrated on empirical studies of innovation and international trade. This was not highly regarded in the world of economics because of the lack of formal theorising. The other strand of work inspired by Schumpeter culminated in the "new evolutionary economics" of Nelson and Winter (Fagerberg, 2003).

Fagerberg (2003) argued that there is a common core within the different strands of evolutionary economics, summarised in three arguments. First, innovation is the main factor behind long run economic development - the more innovation there is the more dynamic the economy will be. Second, evolutionary processes are characterised by strong regularities innovation and imitation, with learning taking place as a result of important innovation. Third, there is a consistent view of actors and cognition - economic knowledge is a set of routines that are reproduced through practice.

Alchian (1950) provided the basis for the development of a new evolutionary economics. He distinguished between "adoption" of a firm by the environment and the conscious process of adaptation to the environment by the firm. Adoption is a blind process, in which those firms that happen to have characteristics that are favoured by the environment thrive, and those firms that have unfavourable characteristics struggle and perhaps fail. Alchian was not arguing that the extreme case of a system which is driven purely by chance processes is realistic. He subsequently moved on to introduce adaptive behaviour by firms. In particular, he discussed strategies of imitation, innovation, and trial and error. Innovation can arise either consciously, or as a result of imperfect imitation. Trial and error may converge to an optimal solution, but for this to happen it must be possible for a trial to be labeled either a success or a failure, and one must be able to move away from local optima in order to reach a global optimum. Alchian assumed that imitation and trial and error are common in reality, and argued that uncertainty provides an excellent reason to imitate observed success. Indeed, there is a substantial amount of management literature around the theme of imitation - what springs to mind most readily is the process of reverse engineering competitors' products, of copying advertising strategies, and of copying service innovations. Alchian concluded that:

"The economic counterparts of genetic heredity, mutations, and natural selection are imitation, innovation, and positive profits." (1950, p220)

\section{Nelson and Winter}

Nelson and Winter began to work out their theory of evolutionary economics in the 1960s and 1970s (for example Nelson \& Winter, 1974, 1980; Winter, 1971), and published the complete results of their research programme in 1982 as An Evolutionary Theory of Economic Change (Nelson \& Winter, 1982). They acknowledged a wide range of intellectual sources and inspirations for their ideas. Prominent among these were Schumpeter, Alchian, and earlier theorists Smith, Malthus and Marx, all of whom referred explicitly to the value of evolutionary 
thinking in economics. The ideas of Simon (1960) and of Cyert and March (1963) were explicitly included in Nelson and Winter's approach - firms were considered to be satisficers rather than optimisers, and were boundedly rational. From Galbraith, Nelson and Winter took the ideas that price competition is less important than other forms of competition (such as advertising and R\&D expenditure) in modern capitalist economies, and that large firms are not simply passive victims of their environment but strive to alter competitive market conditions in their favour. Nelson \& Winter argued that firms strive for profits but do nor or cannot maximise profits. This distinction may be fairly unimportant in stable conditions, but under conditions of dynamic change it matters a great deal.

Nelson \& Winter's evolutionary approach supposes that firms operate according to decision rules which are not based on maximising behaviour. There is no global objective function, no well-defined choice set, and firm behaviour cannot be rationalised in terms of maximising behaviour. Routines are central to the model. They are a persistent feature which determines the possible behaviour of firms, are heritable and selectable - certain routines provide advantages which causes favourable "reproduction" among organisations that use them. Hence, routines play the role of "genes" in this version of evolutionary economics. Routines are put into a threefold classification. Short-run operating characteristics are the routines which are used to make day-to-day decisions. Investment decision routines result in the period-by-period augmentation or diminution of the capital stock. Over and above these routines is a higher-order set of routines for identifying and adopting improved operating characteristics and investment decision routines, these are known as processing routines.

Over time firms use processing routines to seek to improve their operating characteristics and hence their profit performance; this is deemed to be analogous to biological mutation.

Firm behaviour patterns, based on routines, combine with the exogenous state of market demand and supply, to bring about economic outcomes (input prices, output prices, firm profitability). These outcomes determine the relative success of the different firms, and hence their rate of expansion or contraction with the evolutionary system. The dynamic evolutionary process can be described as follows.

1. The operating characteristics and state variables of the firms determine their input and output levels.

2. When combined with market supply and demand conditions (exogenous) these decisions generate the prices of inputs and outputs, and hence firm profitability. 3. Profitability influences the rate of expansion and contraction of the individual firms.

4. This process alone creates dynamic change, since the same routines applied to the new conditions will generate different results. However, there is also mutation of decision rules. After each iteration firms employ their processing routines to seek to improve their operating characteristics and investment decision routines for the subsequent iteration.

5. The joint processes of firm selection and of search cause firms to evolve. The state of the industry at time $t$ dictates a probability distribution for the state of the industry at time $t+1$. This condition explains why stochastic processes and Markov chains are used to model evolutionary economic systems.

Nelson \& Winter's work lends itself readily to modelling using formal mathematical simulations. Indeed, having explained the underlying logic and fundamental assumptions of their evolutionary theory, much of the remainder of the 1982 work is concerned with developing and interpreting simulation models which are designed to illustrate the application of evolutionary economics to standard economic problems - such modelling work has been taken up enthusiastically by later researchers (Andersen, 1994). These analyses are not germane to the present discussion. What is germane to the present discussion is the observation that evolutionary approaches in economics have been subject to certain general criticisms which call into question the legitimacy of this whole approach. It is to those criticisms that we now turn. 


\section{Criticism of evolutionism in economics}

The idea of evolution in economics is most often regarded as a biological analogy. Penrose (1952) provided a general critique of the use of biological analogies in economics. She made a number of general points about analogies in general, and about the use of the biological analogy in economics specifically, while providing a detailed critique of each of three analogies in particular - the life cycle of the firm, viability analysis, and homeostasis. It is her critique of viability analysis (by which she meant the evolutionary approach suggested by Alchian) that concerns us here. Penrose argued that a common characteristic of biological analogies is the wish to avoid the need to use human motives to explain human affairs hence the development of the firm is explained in terms of an abstract life cycle rather than in terms of intentional activity, and the survival and growth of firms is explained by evolutionary processes (adoption by the environment) rather than by motivated human activity. Hence (p812): "Natural selection is substituted for purposive profit-maximising behavior just as in biology natural selection replaced the concept of special creation of species."

In criticising Alchian's ideas, Penrose made two key points. First, that what differentiates man from other animals is his capacity to alter his environment. It is therefore inappropriate to argue that firms are wholly subject to impersonal environmental forces; in many cases firms act to alter the environment. Second, Penrose argued that Alchian's treatment of innovation as an analogue to biological mutation is invalid. A mutation is independent of the environment and of the organism - mutations take place randomly, and those mutations that are beneficial become adaptations that fit the organism better to its environment and promote reproductive success. Innovations, on the other hand, are often direct attempts by the firm to alter the conditions of the environment.

Throughout the paper, Penrose assumed that "viability analysis", derived from evolutionary theory, was a biological analogy. This is understandable, since Alchian was explicitly making the biological analogy. However, more recently evolutionary economists have de-coupled evolution from the biological analogy. Nelson (1995) is an example, and Lawson (2003) has argued along similar lines. The argument is that evolution is a form of change process that is independent of any particular field of study. This provides ammunition to contradict Penrose's general arguments about the dubious nature of biological analogies, without addressing her specific remarks about Alchian's approach.

Rosenberg (1994) is another critic of EE: [p384] "I think that Darwinian theory is a remarkably inappropriate model, metaphor, or theoretical framework for economic theory. The theory of natural selection shares few of its strengths and most of its weaknesses with neoclassical theory, and provides no help in any attempt to frame more powerful alternatives to that theory." A key criticism that Rosenberg levels at the application of Darwinian ideas to economic processes concerns the rate of environmental change. Darwinian natural selection is gradual. It takes many generations for a favourable trait to become widely distributed across a population of organisms. During this period, the environment must continue to favour organisms with that trait - rapid environmental change is a severe constraint on Darwinian evolutionary processes. Two problems arise for economics: first, it is not clear what the economic analogue to a biological generation is, and, second, rapid environmental change is characteristic of the economic world. Nelson and Winter, however, made it clear that their theory was not Darwinian but Lamarckian in character, meaning that acquired characteristics can be inherited. Rosenberg (1994, p405) was scathing about the attempt to rescue EE by invoking Lamarck: "Lamarckianism is, of course, not the label for an alternative theory. It is just a label for the claim that change is not Darwinian. As such it sheds no special light on economic processes, or any other." 


\section{The markets-as-networks approach}

The exposition of the NW approach will be brief in this paper since the readership is assumed to be generally familiar with this research tradition. Since the seminal work in the field was published (Håkansson, 1982) several synoptic articles have followed, upon which this section draws (Ford \& Håkansson, 2005; Håkansson \& Snehota, 2000; Mattsson, 1997; Turnbull, Ford, \& Cunningham, 1996; Turnbull \& Valla, 1986).

The NW approach is based on challenges to certain explicit or implicit assumptions about the manner in which business-to-business exchanges are transacted. These are the assumption that exchange can be fruitfully analysed as discrete transactions, the assumption that industrial markets consist of atomistic buyers and sellers, the assumption that industrial buying and selling can be analysed separately, and the assumption that industrial marketing is concerned with the manipulation by the (active) seller of a marketing mix designed to engage the (passive) buyer in an exchange. In place of these assumptions, the NW approach emphasizes that inter-firm relationships are a common characteristic of industrial markets, that buyer and seller are engaged in a process of interaction, that buyer-seller relationships frequently endure, and that buying and selling must be analysed as simultaneous phenomena. Ford and Håkansson (2005) classified these as a structural challenge (to discrete transactions and atomistic markets) and a process challenge (the importance of interaction) to prior marketing theory. They argued that while the structural challenge had been widely accepted in the world of marketing (that is, acceptance of the importance of enduring relationships), the process challenge had been largely ignored (that is, the significance of interaction had been misunderstood or underestimated). The NW approach is generally conceived as having progressed from the discovery that buyer-seller relationships are a critical characteristic of business markets [IMP1] to the understanding that relationships are inherently inter-connected so that any attempt to understand what happens within a relationship must take account of the network context [IMP2] (Håkansson \& Snehota, 2000).

The various synoptic articles about NW research also refer to the intellectual underpinnings of the research. Originally these were specified as new institutional economics and interorganizational theory - the latter sub-divided into organization-based studies, studies based on several organizations, and studies of the organization in a social context (Håkansson, 1982). Later authors considerably extended this list of claimed intellectual influences. Mattsson (1997) cited dynamic industrial economics, institutional approaches in the social sciences, neo-Austrian economics, macro-organizational studies, economic sociology (cf. Araujo (2004)), research into technological change, and economic history. Håkansson and Snehota (2000) considered organization theory and inter-organizational theory to be intellectual foundations of IMP1, but cited a much wider range of intellectual foundations for IMP2 - institutional marketing, sociology, organization theory, industrial organization, transaction cost economics, business strategy, and even evolutionary economics. Undoubtedly, this breadth of claimed intellectual influences results from the wide range of backgrounds of the researchers who are active within the NW approach. On the one hand it can be claimed a strength, since the willingness to espouse a range of different intellectual traditions in order to try to explain and theorise about empirical phenomena demonstrates a commendable intellectual flexibility. On the other hand it may be deemed a weakness, since the coherence of the NW tradition may have suffered because of a lack of agreement on a common intellectual heritage. Nevertheless, something that is abundantly clear is that neoclassical economics is not regarded as an intellectual precursor to the NW perspective. Rather, the NW perspective is explicitly opposed to the conventional marketing mix view of marketing, which is itself closely associated with neo-classical economics. It is fair to say that, in their own ways, both EE and NW are reactions against neo-classical economics - directly and explicitly in the case of $\mathrm{EE}$, indirectly and through the response to conventional marketing theory (itself derived from neo-classical economics) in the case of NW. 


\section{A comparison of EE and NW}

Table 1: Comparative Analysis of EE and NW

\begin{tabular}{|c|c|c|}
\hline & Evolutionary Economics & Markets-as-Networks \\
\hline Unit of analysis & $\begin{array}{l}\text { Individual firm } \\
\text { Population of firms } \\
\text { Economic system }\end{array}$ & $\begin{array}{l}\text { Inter-firm relationship } \\
\text { Interaction } \\
\text { Network of relationships }\end{array}$ \\
\hline $\begin{array}{l}\text { Methodological } \\
\text { practice, } \\
\text { evidence }\end{array}$ & $\begin{array}{l}\text { Simulation modelling } \\
\text { Qualitative empirical studies }\end{array}$ & $\begin{array}{l}\text { Qualitative empirical studies } \\
\text { Single \& multiple case studies }\end{array}$ \\
\hline $\begin{array}{l}\text { Core } \\
\text { frameworks, } \\
\text { models, } \\
\text { concepts }\end{array}$ & $\begin{array}{l}\text { Routines - operating characteristics } \\
\text { (short-run), investment routines, } \\
\text { processing routines (long-run, } \\
\text { search for better operating routines) } \\
\text { Dynamic evolutionary process - } \\
\text { population, with variation, selection, } \\
\text { and "reproduction", routines acting } \\
\text { as "genes" }\end{array}$ & $\begin{array}{l}\text { Interaction model - interaction } \\
\text { process (episodes, relationships), } \\
\text { interacting parties, interaction } \\
\text { environment, atmosphere } \\
\text { ARA model - actor network (actor } \\
\text { bonds), resource network } \\
\text { (resource ties), activity network } \\
\text { (activity links) }\end{array}$ \\
\hline $\begin{array}{l}\text { Key } \\
\text { assumptions }\end{array}$ & $\begin{array}{l}\text { Heterogeneous, learning firms } \\
\text { Open systems } \\
\text { Path dependence } \\
\text { Innovation (technical progress) } \\
\text { the main factor behind } \\
\text { economic } \\
\text { development } \\
\text { Strong regularities in } \\
\text { evolutionary processes } \\
\text { (innovation, imitation) } \\
\text { Economic knowledge a set of } \\
\text { routines reproduced } \\
\text { through practice }\end{array}$ & $\begin{array}{c}\text { Heterogeneous, learning } \\
\text { firms } \\
\text { Open systems } \\
\text { Path dependence } \\
\text { Technology development } \\
\text { key rationale for } \\
\text { inter-firm } \\
\text { cooperation } \\
\text { are relationships } \\
\text { enduring, relatively } \\
\text { stable } \\
\text { Buyer-seller interaction } \\
\text { involves active } \\
\text { parties } \\
\text { simultaneous } \\
\text { processes }\end{array}$ \\
\hline $\begin{array}{l}\text { Theoretical } \\
\text { antecedents, } \\
\text { origins }\end{array}$ & $\begin{array}{l}\text { Opposition to assumptions of } \\
\text { neoclassical economics } \\
\text { (atomistic markets, } \\
\text { rationality of economic } \\
\text { agents, perfect information, } \\
\text { markets tending towards } \\
\text { equilibrium, neglect of } \\
\text { institutions) } \\
\text { Old institutional economics } \\
\text { Schumpeter \& neo-Schumpeterian } \\
\text { economics } \\
\text { Bounded rationality } \\
\text { Behavioural theory of the firm } \\
\text { J.K. Galbraith - activist firm }\end{array}$ & 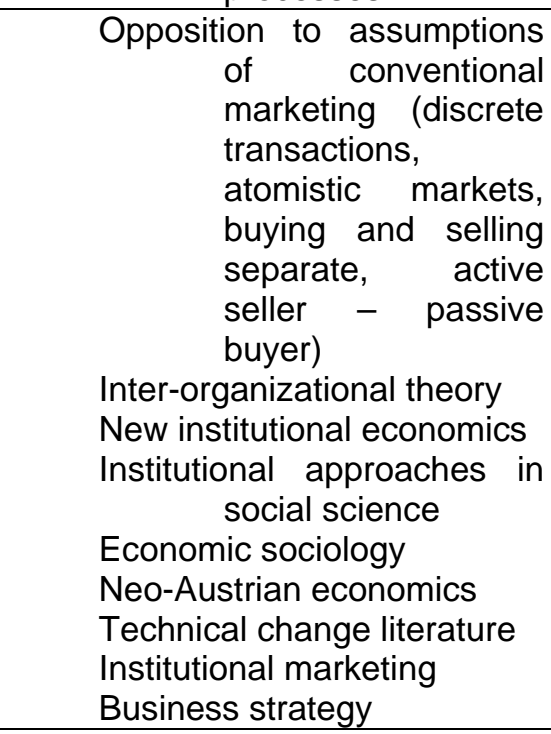 \\
\hline
\end{tabular}


Evolutionary ideas have been touched upon by researchers in the markets-as-networks tradition (Brennan \& Canning, 2004; Brennan, Turnbull, \& Wilson, 2003; Easton, Georgieva, \& Wilkinson, 1997; Hallen, Johanson, \& Seyed-Mohamed, 1991; Snellman, 2001; Young \& Wilkinson, 2004), but there has been no concerted attempt to incorporate evolutionary theory into interaction and network processes. Generally, NW researchers engage in rich, descriptive studies of particular exchange contexts using descriptive, qualitative research methods, and couch their theorising in words rather than in mathematical symbols. The empirical method of EE researchers has become more formalised, usually employing mathematical simulation techniques. Mathematical simulation has only briefly been explored by NW researchers, through the examination of NK models (Easton et al., 1997).

A summary comparison of EE and NW is presented in table 1 . The five dimensions selected for this analysis are the unit of analysis, methodological approach, core frameworks \& concepts, key assumptions, and theoretical antecedents. The NW approach differs from EE (and other traditions in economics) by making the relationship or network the unit of analysis. In common with other economic traditions, EE aspires to be able to explain economic phenomena, in particular economic growth, at the system-wide level. The NW approach has no such system-wide aspirations. Methodologically, neither EE nor NW has made much use of deductive reasoning based on axioms to build formal mathematical methods - this is not surprising, since both contend that the world is too complex to be modelled in this way, and that the heroic simplifying assumptions made in the neoclassical economics tradition render that approach to analysis impotent. It is interesting that the response within the EE tradition has been to pursue simulation (with some supporting idiographic research), while the response within the NW tradition has been to pursue studies of specific situations using qualitative, case study methods (with a small amount of simulation-based research).

The core concepts and framework of new evolutionary economics are the routines which underlie much organizational behaviour (and which can be transformed through the operation of higher-order processing routines) and a dynamic evolutionary process through which organizations with better routines thrive, and better routines become more widely distributed in the system. The EE framework contains a clear, endogenous mechanism for explaining how the characteristics of firms and of the whole population are transformed between time periods. By contrast, the best-known frameworks of the NW tradition are essentially static descriptions rather than dynamic, process models. The original (IMP1) Interaction Model focuses on the elements of the dyadic inter-firm relationship. The later (IMP2) ActorsResources-Activities model conceptualizes the industrial system as comprising three interconnected networks. The actor network is responsible for maintaining, managing and developing the network of resources, which in turn permits the functioning of the system through the coordination of linked activities. Naturally, it is assumed that change is a continuous part of the A-R-A model, for example as actors continually try to improve their network position, as new resources are added to the network, necessitating the development of new resource ties and the alteration of existing activity links. However, no explicit (endogenous) process is contained within the model to explain how the model is transformed from $A-R-A$ at time $t 1$, into an altered $A *-R *-A *$ state at time t2.

At the levels of key assumptions and theoretical antecedents there are manifest overlaps between EE and NW. Both research traditions hold that firms are heterogeneous, that firms learn, that learning is an important part of the firm (relationship) development process, and that firm (relationship, network) development exhibits path dependence. Technology development is important to both perspectives, as is some conception of stability or regularity - inter-firm relationships do not just appear and disappear (NW), and evolution within a population of firms exhibits a degree of regularity (EE). In terms of their theoretical antecedents, both of these research traditions emerged, in their modern guise, during the 1960s and 1970s, and for both of them 1982 was a pivotal year with the publication of a seminal book. It is, therefore, hardly surprising that the researchers involved were to some extent influenced by the same intellectual trends that were emergent in the middle years of 
the twentieth century. Both EE and NW are components of the reaction against the hegemony of neoclassical economics; both are "institutionalist" in the broad sense of accepting the fundamental premise that institutions matter in human social and economic organization. Both readily accept that the assumptions of bounded rationality and satisficing apply to economic behaviour in organizations.

It should be acknowledged that the ambitions of the NW research tradition are inherently narrower than those of EE. The ultimate theoretical success of EE would result in its replacement of neoclassical economics as the dominant economic paradigm. Discussion of the great economic issues of the day, such as government economic policy and economic growth, would be couched in evolutionary terms rather than in the standard competitive markets terminology of neoclassical economics. On the other hand, the ultimate theoretical success of the NW tradition would result only in the complete replacement of the "marketing mix" approach as an organising framework for analysing business-to-business markets and marketing.

\section{Conclusion}

The first and most fundamental question to be addressed is whether or not there is any point at all in comparing the EE and NW research traditions. Let us accept that, since both research traditions are concerned with explaining phenomena in the socio-economic world, in particular the way in which industrial systems function, there is a prima facie case for such a comparison to be made. It would be invalid to argue that the comparison is pointless because the traditions have completely different explanada, since this is manifestly not so. However, one might argue that although there is a superficial intellectual connection between the two based on common intellectual ancestry, they have taken such divergent intellectual paths that anything other than an elementary comparison between the two is pointless. In this case, one might note the common ancestry, express polite interest in the different paths they have taken, and then suggest that each continues with its own research agenda since there is unlikely to be scope for useful cross-fertilisation. This is certainly a defensible position. In particular, economic researchers examining the NW tradition might well contend that what is there is an array of interesting context-specific qualitative studies which are only very loosely connected together by any kind of theoretical framework. Researchers in the NW tradition may well respond that institutional economics showed some promise, and that the new evolutionary economics perhaps once had its heart in the right place, but that the excessive concentration on formalisation through mathematical simulations has caused it to - in the end - commit a very similar error to neo-classical economics; namely, sacrificing realism on the altar of mathematical precision.

In this paper, however, it is argued that the comparison between EE and NW is about more than simple intellectual curiosity, and that the scope for cross-fertilisation extends beyond a simple acknowledgment of the presence and of the similar intellectual roots of the other tradition. Both emerged from similar concerns about the inadequacy of conventional models to explain observed economic phenomena, pursue similar goals associated with understanding inter-organizational exchange processes, share many assumptions, and seek to explain similar phenomena. Yet they developed in rather different ways, with EE principally using dynamic simulation modelling to explain how different types of organization grow and thrive within a population through time, and NW principally using qualitative case study analysis to examine the detail of inter-organizational relationships and networks. It is tempting to suggest a direct and simplistic complementarity between the two: EE provides a vehicle for understanding dynamic change processes within organizational populations but lacks a detailed "micro-theory" of exchange, while NW provides the "micro-theory" of organizational exchange but lacks a "macro-theory" of system-wide change. There may be some truth to this. 
However, this is to ignore the fundamental difference in the unit of analysis that some authors would claim exists between the two traditions. For EE, there is no doubt that the firm and the population of firms are the unit of analysis - this is not a matter for debate at all. For NW, there is a debate about the appropriate unit of analysis. Ford and Håkansson have recently argued that making the space between firms the unit of analysis is central to the contribution from this perspective - and yet is frequently misunderstood or ignored.

What is missing in the NW perspective is a coherent theory of change within interorganizational relationships and networks. The relationship life-cycle has been generally rejected as a sound theory of change (Ford, 1989; Turnbull et al., 1996), even though it may be a useful didactic tool. An evolutionary perspective could add a coherent theory of change to the NW tradition. By examining EE we can identify a potentially fruitful research agenda within NW. In particular, EE posits that many business decisions are governed by rather simple decision rules which were dubbed routines by Nelson and Winter. These routines act as the equivalent of genes - they act as a key source of the continuity of behaviour that is needed if the industrial system is to be shaped by an evolutionary process. If Nelson and Winter's theory is correct then evolutionary processes must play an important part in the dynamic change process of inter-organizational relationships and networks. Relationship management routines, network management routines, and inter-organizational routines, must play an important "genetic role" within this process. Routines are considered to be multiperson skills for coordinating productive activities, and to consist largely of tacit knowledge (Winter, 2005). Much knowledge of the nature of these routines must already exist in the extensive database of inter-organizational case studies developed in the NW tradition. What is needed is not so much further empirical work to systematically identify and classify interorganizational routines (although that may also be necessary), but an examination of the existing body of case study information using an EE conceptual framework to try to systematise what is already known.

What is missing in the EE perspective, if the research results from NW studies are to be believed, is an appreciation of the importance of inter-organizational routines. Routines have been conceptualised as "belonging to" individual firms. NW case studies have shown that routines can be shared by two or more firms. An appreciation that routines may be "owned", imitated, and innovated at a level higher than the individual firm could enrich the EE tradition. Whether inter-organizational routines are tractable in terms of the methods of formal (simulation) analysis preferred by evolutionary economists is an open question. In any event, before attempting to incorporate the idea into formal modelling, there is further conceptual work to be done to understand the potentially serious implications of permitting routines to exist in the space between firms, when previously firms have been treated as hermetically sealed units interacting only through formal exchange mechanisms.

Finally, the question arises of the general merit of conducting comparative analyses of the NW tradition with other cognate traditions in the social and management sciences. In contrast to much research in marketing of an explicitly managerial orientation, markets-as-networks research seems often to aspire to the status of social science - a claim made on its behalf by Mattsson (1997), for example. An explicit concern for intellectual ancestry and explicit consideration of the ontological and epistemological basis for knowledge claims are also, in the opinion of this author, identifying characteristics of much NW research. As a consequence, rather than simply hoping to communicate with a managerial audience through the medium of elementary taxonomies or checklists, it seems to be an aspiration of many members of the NW research tradition to communicate with social scientists. It is fair to say that, in general, for most marketing researchers any communication with social science is purely one-way traffic, with marketers borrowing whatever ideas suit their purpose at the time and offering little in return. A tentative suggestion - the NW research tradition will have come of age intellectually when social scientists from other disciplines sit up, take note, and appreciate that they must incorporate NW ideas into their theorising. An apologia for the present work - a legitimate role of the NW researcher is to try to understand other cognate 
research traditions, to seek to identify ways in which their insights can benefit NW research, and ways in which the insights from NW research can, in turn, enrich those other traditions.

\section{References}

Alchian, A. A. (1950). Uncertainty, Evolution, and Economic Theory. Journal of Political Economy, LVIII, 211-221.

Andersen, E. S. (1994). Evolutionary Economics: Post-Schumpeterian Contributions. London: Pinter.

Araujo, L. (2004). Markets, Market Making and Marketing. Paper presented at the IMP annual conference, Copenhagen.

Brennan, R., \& Canning, L. E. (2004, September). Towards an enrichment of the IMP concept of adaptations. Paper presented at the IMP Group Annual Conference, Copenhagen.

Brennan, R., Turnbull, P. W., \& Wilson, D. T. (2003). Dyadic adaptation in business markets. European Journal of Marketing, 37(11), 1636-1665.

Callon, M., Méadel, C., \& Rabeharisoa, V. (2002). The economy of qualities. Economy and Society, 31(2), 194-217.

Cyert, R. M., \& March, J. G. (1963). A Behavioral Theory of the Firm. Englewood Cliffs, NJ: Prentice-Hall.

Easton, G., Georgieva, C., \& Wilkinson, I. (1997). On the Edge of Chaos: Towards Evolutionary Models of Industrial Networks. In H.-G. Gemunden, T. Ritter \& A. Walter (Eds.), Relationships and Networks in International Markets (pp. 273-294). Oxford: Elsevier/Pergamon.

Fagerberg, J. (2003). Schumpeter and the revival of evolutionary economics: an appraisal of the literature. Journal of Evolutionary Economics, 13, 125-159.

Ford, D. (1989). One more time, what buyer-seller relationships are all about. Paper presented at the 5th IMP Conference, State College/University Park, Pennsylvania.

Ford, D., \& Håkansson, H. (2005). IMP - Some things achieved: Much more to do. European Journal of Marketing, Forthcoming.

Foster, J. (1991). The Institutionalist (Evolutionary) School. In D. Mair \& A. G. Miller (Eds.), A Modern Guide to Economic Thought: An Introduction to Comparative Schools of Thought in Economics. Aldershot: Edward Elgar.

Galbraith, J. K. (1967). The New Industrial State. Boston: Houghton Mifflin.

Gee, J. M. A. (1991). The Neoclassical School. In D. Mair \& A. G. Miller (Eds.), A Modern Guide to Economic Thought (pp. 71-108). Aldershot: Edward Elgar.

Grattan-Guinness, I. (2002). "In some parts rather rough": A Recently Discovered Manuscript Version of William Stanley Jevons's "General Mathematical Theory of Political Economy" (1862). History of Political Economy, 34(4), 685-726.

Håkansson, H. (Ed.). (1982). International Marketing and Purchasing of Industrial Goods. Chichester: John Wiley and Sons. 
Håkansson, H., \& Snehota, I. (2000). The IMP Perspective, Assets and Liabilities of Relationships. In J. N. Sheth (Ed.), Handbook of Relationship Marketing. Thousand Oaks: Sage.

Hallen, L., Johanson, J., \& Seyed-Mohamed, N. (1991). Interfirm Adaptations in Business Relationships. Journal of Marketing, 55, 29-37.

Hodgson, G. M. (1993). Economics and Evolution: Bringing Life Back into Economics. Cambridge: Polity Press.

Jevons, W. S. (1871/1970). The Theory of Political Economy (Pelican Classics ed.). Harmondsworth: Pelican.

Lawson, T. (2003). Reorienting Economics. London: Routledge.

Loasby, B. J. (2001). The Evolution of Knowledge. Paper presented at the DRUID Conference, Aalborg.

Mattsson, L.-G. (1997). "Relationship Marketing" and the "Markets-as-Networks Approach" - a comparative analysis of two evolving streams of research. Journal of Marketing Management, 13(5), 447-462.

Miller, A. G., \& Mair, D. (1991). Introduction. In D. Mair \& A. G. Miller (Eds.), A Modern Guide to Economic Thought (pp. 1-20). Aldershot: Edward Elgar.

Miller, D. (2002). Turning Callon the right way up. Economy and Society, 31(2), 218-233.

Nelson, R. R., \& Winter, S. G. (1974). Neoclassical vs. Evolutionary Theories of Economic Growth: Critique and Prospectus. Economic Journal(December), 886-905.

Nelson, R. R., \& Winter, S. G. (1980). Firm and Industry Response to Changed Market Conditions: An Evolutionary Approach. Economic Inquiry, XVIII(2), 179-202.

Nelson, R. R., \& Winter, S. G. (1982). An Evolutionary Theory of Economic Change. Cambridge, Mass.: Harvard University Press.

Penrose, E. (1952). Biological Analogies in the Theory of the Firm. The American Economic Review, 804-819.

Rosenberg, A. (1994). Does evolutionary theory give comfort or inspiration to economics? In P. Mirovski (Ed.), Natural Images in Economic Thought. Cambridge: Cambridge University Press.

Schumpeter, J. A. (1954). History of Economic Analysis. London: George Allen \& Unwin.

Simon, H. A. (1960). The New Science of Management Decision. Englewood Cliffs, NJ: Prentice-Hall.

Snellman, K. (2001). Evolution of Exchange Relationships: Past Research and Future Directions. Paper presented at the 17th Annual IMP Conference, Oslo.

Turnbull, P. W., Ford, D., \& Cunningham, M. T. (1996). Interaction, Relationships and Networks in Business Markets: An Evolving Perspective. Journal of Business \& Industrial Marketing, 11(3/4), 44-62.

Turnbull, P. W., \& Valla, J.-P. (1986). Strategies for International Industrial Marketing: the Management of Customer Relationships in European Industrial Markets. London: Croom Helm. 
Veblen, T. (1898). Why is Economics not an Evolutionary Science? Quarterly Journal of Economics, 12, 373-397.

Veblen, T. (1899). The Theory of the Leisure Class: An Economic Study of Institutions. London: MacMillan.

Williamson, O. E. (1975). Markets and Hierarchies: Analysis and Antitrust Implications. New York: The Free Press.

Winter, S. G. (1971). Satisficing, Selection, and the Innovating Remnant. Quarterly Journal of Economics, 85(2), 237-261.

Winter, S. G. (2005). Developing Evolutionary Theory for Economics and Management.Unpublished manuscript, Philadelphia, PA.

Young, L., \& Wilkinson, I. (2004). Evolution of Networks and Cognitive Balance. Paper presented at the 20th Annual IMP Conference, Copenhagen. 